\title{
EFFECT OF ANTIOXIDANTS AND POTASSIUM ON PRODUCTIVITY OF SUNFLOWER IN SANDY SOIL
}

\author{
Salem, Emad M.M.* and Hosam A. Shoman \\ Department of Plant Production, Desert Research Center, El- \\ Matareya, Cairo, Egypt \\ *E-mail: emadmms@yahoo.com
}

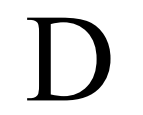

uring two summer seasons of 2015 and 2016, the influence of antioxidants application and potassium levels on productivity of sunflower was estimated under sandy soil conditions. Antioxidants (nil antioxidants; tap water only; vitamin E, 50 ppm; vitamin C, 100 ppm; citric acid, 500 ppm and vitamin $\mathrm{E}+$ vitamin $\mathrm{C}+$ citric acid at the same levels used individually for each). Potassium levels included 0, 24, 36 and $48 \mathrm{~kg} \mathrm{~K}_{2} \mathrm{O}$ /feddan $(0.42$ hectar). Results showed that both antioxidants application and potassium levels treatments had remarkable effects on plant height, head diameter, number of seeds/head, 1000 seed weight, seed and oil yields as well as percentages of harvest index, shelling, seed protein and seed oil in both seasons. Maximum values of such tested traits were commonly recorded with using vitamin $\mathrm{E}+$ vitamin $\mathrm{C}+$ citric acid. Increasing potassium level from 0 to $48 \mathrm{~kg} \mathrm{~K}_{2} \mathrm{O}$ /feddan caused significant increases in all traits of sunflower plants and the highest values were obtained at $48 \mathrm{~kg} \mathrm{~K}_{2} \mathrm{O}$ /feddan in both seasons. All studied traits were significantly affected by the interaction between antioxidants application and potassium levels, except harvest index and seed protein percentage.

Keywords: sunflower, antioxidants, potassium, sandy soil, oil yield

In Egypt, there is a great challenge to fulfill the demand of edible oils for the population, where the approximate amount of edible oil imports is 95 to $97 \%$ form various countries (Anonymous, 2013). Increasing oil yield production is considered one of the most important national aims to face the great demand of the highly increasing human population and decreasing the gap between the production and population consumption, which exceeds $95 \%$. That could be achieved by improving agricultural practices and enhancing the ability of plants under the conditions of desert areas to cope the different stresses, especially heat stress that directly causes molecular damage to plants or indirectly through formation of reactive oxygen species (ROS) (Farooq et al., 2009). Sunflower (Helianthus annuus L.) is considered as one of the four important annual crops in the world for edible oil. 
Sunflower seeds contain $24-49 \%$ of oil and the husks contain $25-35 \%$ of protein, which is mostly feed to livestock because of its high biological value. Furthermore, sunflower seeds are eaten as salted whole seeds as roasted nut meats. Moreover, oil is characterized by its high content of unsaturated fatty acids; such as oleic and linoleic, which represent $90 \%$ of total fatty acids (Saleh et al., 2004). High temperature leads to the production of ROS; such as $\mathrm{H}_{2} \mathrm{O}_{2}$, hydroxyl ions, singlet oxygen etc. (Foyer et al., 2009). So, improving heat tolerance of plant is a viable approach to resolve this problem induced by global warming. It is necessary to find out the responses of plants to heat stress and their fundamental physiological mechanisms, as it can provide insights into how plants may be modified to develop into more tolerant (Wang et al., 2010). Antioxidants intercept free radicals and protect cells from the oxidative damage that leads to aging and disease (Karadeniz et al., 2005). Antioxidants as active oxygen scavengers could be beneficial in the protection of the structure and function of the photosystems against excess light (Rajagopal et al., 2005).

Antioxidants play role in the reduction or prevention of enzymatic browning by inhibiting polyphenol oxidase (Maurice et al., 2000). These compounds have beneficial effects on catching ROS that are likely formed during photosynthesis and respiration processes. Leaving these free radicals without chelating or catching lead to lipids oxidation, loss of plasma membrane permeability and cause death of cell. Antioxidants, i.e. vitamins $\mathrm{A}, \mathrm{C}$ and $\mathrm{E}$, carotenoids, phenols, glutathione and citric acid due to their molecules that may act as cofactors for some specific enzymes, i.e., dismutase's, catalases, peroxidases, those catalyzed breakdown of the toxic $\mathrm{H}_{2} \mathrm{O}_{2}, \mathrm{OH}, \mathrm{O}^{-2}$ radicals (Aono et al., 1993). Previously, competent researchers emphasized the beneficial effects of antioxidants on growth characters, leaf chemical composition, yield and yield components of different horticultural crops (Gad El-Hak et al., 2002; Abd El-Hakim, 2006; Ali et al., 2006; Ibrahim, 2010 and Abdou et al., 2011). Also, Al-Qubaie (2012) and Osman et al. (2014) stated that foliar application of antioxidants alleviated harmful effect of free radicals as well as promoted and increased yield and yield attributes of sunflower plants.

Potassium plays a particular role in stress physiology, as it contributes mostly to the tolerance of plants to various environmental stresses (Cakmak, 2005 and Jan and Hadi, 2015). Also, K increases water uptake and transport in plants and controls osmotic pressure that is vital particularly under heat stress conditions (Marchand, 2007). Sunflower is very demanding in $\mathrm{K}$, exceeding crops such as corn and soybeans (Uchoa et al., 2011). Potassium is the element that mostly influences the growth and production of sunflower (Prado and Leal, 2006). The increase in agricultural productivity, resulting from the addition of $\mathrm{K}$ fertilizers to the soil, mainly varies with the amount of available $\mathrm{K}$ and soil fertility (Feitosa et al., 2013). However, the semiarid region is characterized by low natural soil fertility

Egyptian J. Desert Res., 68, No. 1, 61-74 (2018) 
(Menezes and Oliveira, 2008). Thus, the use of supplementary $\mathrm{K}$ fertilizer is indispensable for obtaining good crop yields. Therefore, the present investigation aimed to study the response of sunflower plants yield and its components to foliar application of antioxidants as well as determining the optimum potassium fertilizers rates for improving the productivity under sandy soil conditions.

\section{MATERIALS AND METHODS}

\section{Site Description}

In sandy soil condition, two field experiments were carried out at Baloza Station of the Desert Research Center, North Sinai Governorate during two consecutive seasons of 2015 and 2016. Physical and chemical soil properties of the studied site were measured according to Klute (1986), and recorded in table (1). Also, chemical analysis of irrigation water was assessed using the standard method of Page et al. (1982) and presented in table (2).

Table (1): Physical and chemical properties of the experimental soil.

\begin{tabular}{|c|c|c|c|c|c|c|c|c|c|c|c|c|c|c|}
\hline \multicolumn{3}{|c|}{$\begin{array}{c}\text { Particle size } \\
\text { distribution (\%) }\end{array}$} & \multirow[b]{2}{*}{ Texture } & \multirow{2}{*}{$\begin{array}{c}\mathrm{EC} \\
\left(\mathrm{dSm}^{-1}\right)\end{array}$} & \multirow[b]{2}{*}{$\mathbf{p H}$} & \multicolumn{5}{|c|}{ Available cations } & \multicolumn{4}{|c|}{$\begin{array}{c}\text { Available anions } \\
(\mathrm{meq} / \mathrm{l})\end{array}$} \\
\hline Sand & Silt & Clay & & & & $\begin{array}{c}\mathbf{P} \\
(\%)\end{array}$ & $\begin{array}{c}K \\
(\%)\end{array}$ & $\begin{array}{l}\mathrm{Na} \\
(\%)\end{array}$ & $\begin{array}{c}\mathrm{Ca} \\
(\mathrm{meq} / \mathrm{l})\end{array}$ & $\begin{array}{c}\text { Mg } \\
(\mathrm{meq} / \mathrm{l})\end{array}$ & $\mathrm{CO}_{3}{ }^{--}$ & $\mathrm{HCO}_{3}^{-}$ & $\mathrm{Cl}^{-}$ & $\mathrm{SO}_{4}$ \\
\hline 91 & 5 & 4 & Sandy & 1.29 & 8 & 0.39 & 0.51 & 4.54 & 3.42 & 4.11 & - & 3.62 & 3.0 & 5.8 \\
\hline
\end{tabular}

Table (2). Chemical analysis of irrigation water.

\begin{tabular}{|c|c|c|c|c|c|c|c|c|c|c|c|}
\hline \multirow{2}{*}{ Season } & \multirow{2}{*}{$\mathbf{p H}$} & \multirow[b]{2}{*}{$\begin{array}{c}\text { E.C. } \\
\text { (ppm) }\end{array}$} & \multirow{2}{*}{ S.A.R } & \multicolumn{4}{|c|}{ Soluble cations (meq/l) } & \multicolumn{4}{|c|}{ Soluble anions (meq/l) } \\
\hline & & & & $\mathrm{Ca}^{++}$ & $\mathbf{M g}^{++}$ & $\mathrm{Na}^{+}$ & $\mathbf{K}^{+}$ & $\mathrm{CO3}^{=}$ & $\mathrm{HCO}_{3-}$ & $\mathrm{SO}^{=}$ & $\mathrm{Cl}^{-}$ \\
\hline 2015 & 7.63 & 1411 & 3.55 & 3.41 & 3.12 & 8.47 & 0.63 & 0.17 & 3.22 & 2.38 & 7.47 \\
\hline 2016 & 7.74 & 1355 & 3.18 & 3.54 & 3.25 & 7.36 & 0.58 & 0.32 & 3.68 & 2.79 & 8.24 \\
\hline
\end{tabular}

\section{Experimental Treatments and Procedures}

The study aimed to investigate the sunflower cultivar Giza 102 response to five treatments of antioxidants foliar application [vitamin E ( $\alpha$ tocopherol) at $50 \mathrm{ppm}$, vitamin $\mathrm{C}$ (ascorbic acid) at $100 \mathrm{ppm}$, citric acid at $500 \mathrm{ppm}$, vitamin $\mathrm{E}+$ vitamin $\mathrm{C}+$ citric acid in addition to tap water as a control treatment] as well as four levels of $\mathrm{K}$ fertilizer levels [0, 24, 36 and $48 \mathrm{~kg} \mathrm{~K}_{2} \mathrm{O}$ /feddan ( 0.42 hectar)]. The antioxidants treatments were sprayed four times at 30, 40, 50 and 60 days after sowing (DAS) using a knapsack sprayer with one nozzle and the carrier was $300 \mathrm{~L}$ water/feddan. Moreover, plots received $\mathrm{K}$ fertilizer were treated at 50 days from sowing. Each 
treatment was replicated three times on split plot design, where the main plots were occupied with antioxidants treatments and the sub plots were allotted with $\mathrm{K}$ fertilizer levels.

Prior planting and during land preparation, organic manure at a rate of $15 \mathrm{~m}^{3} /$ feddan and calcium super-phosphate $15.5 \% \mathrm{P}_{2} \mathrm{O}_{5}$ at a rate of 150 $\mathrm{kg} /$ feddan were applied. Sunflower was planted on the 1st of May in both growing seasons in hills $25 \mathrm{~cm}$ apart on ridges $60 \mathrm{~cm}$ width and 3.5 meter length at 21 DAS, plants were thinned to secure one plant per hill, then fertilized with nitrogen fertilizer in the form of ammonium sulphate; $20.5 \%$ $\mathrm{N}$ at a rate of $100 \mathrm{~kg} \mathrm{~N} /$ feddan, the experimental plot area was $3.5 \mathrm{~m} \times 3 \mathrm{~m}$ $\left(10.5 \mathrm{~m}^{2}\right)$. The preceding crop was faba bean and all agricultural practices for sunflower were followed according to the recommendation of Egyptian Ministry of Agriculture throughout the two experimental seasons.

\section{Assessments}

At heading, heads of ten plants were chosen at random from external ridges of each plot and bagged at early seed development to avoid bird's damage until maturity. Sunflower plants were hand-harvested at the stage of physiological maturation, when the back of the head has turned from green to yellow and the bracts are turning brown. At harvest (115 and 121 DAS in $1^{\text {st }}$ and $2^{\text {nd }}$ seasons, respectively), a sample of ten guarded plants were taken randomly from each plot to measure plant height, head diameter, number of seeds per head and 1000-seed weight. Moreover, all plants of the experimental unit were collected to evaluate biological and seed yields. Additionally, harvest index and shelling percentage as described by Beadle (1987) was computed. According to A.O.A.C. (1995), seed protein percentage (multiplying $\mathrm{N}$ in seed by 6.25) and oil percentage (using Soxhlet apparatus and petroleum ether was a solvent). Also, oil yield was computed by multiplying oil \% in the seeds by seed yield.

\section{Statistical Analysis}

All the obtained data from each season were subjected to the proper statistical analysis of variance according to Mead et al. (1993) and L.S.D at $5 \%$ level of significance was used for the comparison between means.

\section{RESULTS AND DISCUSSION}

The findings in tables ( 3 and 4) can be illustrated and interpreted under the three main headings as follows:

\section{Antioxidants}

Application of antioxidant treatments significantly affected all studied sunflower traits in 2015 and 2016 seasons (Tables 3 and 4). Sunflower plants treated with each of antioxidant as individual application, via citric acid, vitamin $\mathrm{E}$ and vitamin $\mathrm{C}$ or in combination via citric acid + vitamin $\mathrm{E}+$ vitamin $\mathrm{C}$ surpassed the untreated ones in producing the 
maximum values of plant height, head diameter, seeds number/head, 1000seed weight and seed yield (Table 3). Among the applied antioxidants, spraying of the combination of (citric acid + vitamin E + vitamin C) was the potent pattern for enhancing such traits. Foliar application of vitamin $\mathrm{E}$ alone came in descending order, followed by citric acid and eventually vitamin $\mathrm{C}$ in this respect. Moreover, the differences between citric acid + vitamin E + vitamin $\mathrm{C}$ and vitamin $\mathrm{E}$ alone did not reach the 5\% level of significance for plant height (in 2016) as well as 1000-seed weight (in both seasons). As averages of the two seasons, the increments in plant height, head diameter, seeds number/head, 1000-seed weight and seed yield due to supplying sunflower plants by citric acid + vitamin $\mathrm{E}+$ vitamin $\mathrm{C}$ treatment amounted to $19.4,59.1,48.5,34.5$ and $30.8 \%$, respectively, relative to the control.

On the other hand, the tested traits via harvest index $\%$, shelling $\%$, protein $\%$, oil $\%$ and oil yield were also markedly influenced by application of antioxidants in 2015 and 2016 seasons (Table 4). In this connection, citric acid + vitamin $\mathrm{E}+$ vitamin $\mathrm{C}$ treatment along with vitamin $\mathrm{E}$ treatment achieved the highest values of harvest index $\%$, shelling $\%$, oil $\%$ and oil yield. While, protein $\%$ showed the maximum equaled value with each of citric acid + vitamin $\mathrm{E}+$ vitamin $\mathrm{C}$ treatment and vitamin $\mathrm{C}$ one. It could be explained that foliar application of antioxidants alleviate the harmful effect of biotic and abiotic stresses on many metabolic and physiological processes of plant; such as cell division, synthesis of enzymes, photosynthetic pigments, chlorophyll content, membrane system in cell, photosynthesis, photoprotection that reflected in increasing yield and quality of treated plants. These findings are in agreement with those reported by El-Bassiouny et al. (2005), Reda et al. (2005), Ali et al. (2006), Farooq et al., 2009, Abdou et al. (2011), Muhammad et al. (2011), Al-Qubaie (2012), Kamal et al. (2017) and Sadiq et al. (2017).

Being vitamin $\mathrm{C}$ participates in a variety of processes, including photosynthesis, cell wall growth and cell expansion, resistance to environmental stresses and synthesis of ethylene, gibberellins, anthocyanin and hydroxyl Proline (Galal et al., 2000 and Smirnoff and Wheeler, 2000), it enhances yield and its components. 
Table (3). Effect of antioxidants and potassium levels and their interaction on yield and yield components of sunflower during 2015 and 2016 growing seasons.

\begin{tabular}{|c|c|c|c|c|c|c|c|c|c|c|c|}
\hline \multirow{2}{*}{\multicolumn{2}{|c|}{ Treatment }} & \multicolumn{2}{|c|}{$\begin{array}{l}\text { Plant height } \\
\text { (cm) }\end{array}$} & \multicolumn{2}{|c|}{$\begin{array}{c}\text { Head } \\
\text { diameter } \\
(\mathrm{cm}) \\
\end{array}$} & \multicolumn{2}{|c|}{$\begin{array}{c}\text { No. of } \\
\text { Seeds/head }\end{array}$} & \multicolumn{2}{|c|}{$\begin{array}{c}1000- \\
\text { Seed weight } \\
(\mathrm{g})\end{array}$} & \multicolumn{2}{|c|}{$\begin{array}{l}\text { Seed yield } \\
(\mathrm{kg} / \mathrm{fed})\end{array}$} \\
\hline & & 2015 & 2016 & 2015 & 2016 & 2015 & 2016 & 2015 & 2016 & 2015 & 2016 \\
\hline \multicolumn{12}{|c|}{ Antioxidant, ppm (A) } \\
\hline \multirow{5}{*}{\multicolumn{2}{|c|}{$\begin{array}{l}\text { Without, 0 } \\
\text { Citric acid, } 500 \\
\text { Vitamin E, 50 } \\
\text { Vitamin C, 100 } \\
\text { Citric acid+vitamins E }\end{array}$}} & 135.2 & 137.5 & 11.1 & 11.8 & 573.2 & 591.7 & 52.1 & 55.7 & 961 & 972 \\
\hline & & 152.1 & 153.9 & 15.1 & 15.7 & 702.6 & 730.0 & 65.5 & 67.0 & 1080 & 1097 \\
\hline & & 157.2 & 160.7 & 16.2 & 16.5 & 787.0 & 792.1 & 69.8 & 71.6 & 1152 & 1201 \\
\hline & & 147.3 & 149.5 & 13.5 & 13.8 & 663.3 & 693.4 & 58.7 & 60.4 & 1011 & 1044 \\
\hline & & 161.6 & 164.0 & 17.9 & 18.5 & 857.4 & 871.7 & 71.4 & 73.5 & 1243 & 1285 \\
\hline \multirow{2}{*}{\multicolumn{2}{|c|}{$\begin{array}{l}\text { LSD }_{0.05} \\
\text { Potassium sulphate, } \mathrm{kg}\end{array}$}} & 3.4 & 3.7 & 0.6 & 0.8 & 33.7 & 35.4 & 2.5 & 2.8 & 41.6 & 38.9 \\
\hline & & & & & & & & & & & \\
\hline \multicolumn{2}{|l|}{$\mathbf{0}$} & 129.4 & 131.5 & 12.4 & 12.9 & 586.7 & 602.5 & 45.2 & 49.4 & 942 & 951 \\
\hline \multicolumn{2}{|l|}{24} & 139.1 & 140.8 & 15.6 & 16.5 & 723.1 & 741.3 & 60.8 & 62.5 & 1075 & 1098 \\
\hline \multicolumn{2}{|l|}{36} & 144.9 & 147.6 & 16.9 & 17.2 & 798.3 & 817.3 & 69.6 & 70.9 & 1155 & 1174 \\
\hline \multicolumn{2}{|l|}{48} & 162.7 & 164.9 & 19.7 & 20.1 & 872.3 & 881.6 & 77.1 & 80.4 & 1315 & 1372 \\
\hline \multicolumn{2}{|l|}{$\mathbf{L S D}_{\mathbf{0 . 0 5}}$} & 7.4 & 6.7 & 1.1 & 1.3 & 36.2 & 38.0 & 3.7 & 2.9 & 53.4 & 50.9 \\
\hline \multicolumn{12}{|l|}{$A \times P$} \\
\hline \multirow{4}{*}{$\sum_{0}^{\stackrel{E}{E}}$} & $\mathbf{0}$ & 132.1 & 134.3 & 11.5 & 12.3 & 578.8 & 595.9 & 48.6 & 52.5 & 949 & 959 \\
\hline & 24 & 136.9 & 138.9 & 13.1 & 14.1 & 646.9 & 665.2 & 56.4 & 59.0 & 1016 & 1033 \\
\hline & 36 & 139.8 & 142.3 & 13.7 & 14.5 & 684.4 & 703.1 & 60.7 & 63.2 & 1055 & 1070 \\
\hline & 48 & 148.7 & 150.9 & 15.1 & 15.9 & 721.3 & 735.2 & 64.5 & 67.9 & 1135 & 1169 \\
\hline \multirow{4}{*}{ : } & 0 & 140.5 & 142.4 & 13.7 & 14.3 & 643.4 & 664.9 & 55.3 & 58.1 & 1009 & 1022 \\
\hline & 24 & 145.3 & 147.1 & 15.3 & 16.1 & 711.4 & 734.2 & 63.0 & 64.6 & 1075 & 1095 \\
\hline & 36 & 148.2 & 150.5 & 16.0 & 16.4 & 749.0 & 772.1 & 67.4 & 68.8 & 1115 & 1133 \\
\hline & 48 & 157.1 & 159.1 & 17.4 & 17.9 & 785.9 & 804.2 & 71.2 & 73.6 & 1195 & 1232 \\
\hline \multirow{4}{*}{ 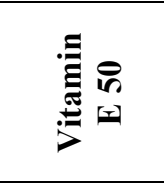 } & $\mathbf{0}$ & 143.0 & 145.8 & 14.3 & 14.7 & 685.5 & 695.9 & 57.4 & 60.4 & 1044 & 1073 \\
\hline & 24 & 147.9 & 150.5 & 15.9 & 16.5 & 753.6 & 765.2 & 65.2 & 66.9 & 1111 & 1147 \\
\hline & 36 & 150.8 & 153.9 & 16.5 & 16.8 & 791.1 & 803.1 & 69.6 & 71.1 & 1151 & 1185 \\
\hline & 48 & 159.7 & 162.5 & 17.9 & 18.3 & 828.0 & 835.2 & 73.3 & 75.9 & 1231 & 1284 \\
\hline \multirow{4}{*}{ 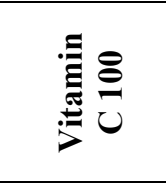 } & $\mathbf{0}$ & 138.1 & 140.2 & 12.9 & 13.3 & 623.8 & 646.7 & 51.9 & 54.8 & 974 & 995 \\
\hline & 24 & 142.9 & 144.9 & 14.5 & 15.1 & 691.8 & 715.9 & 59.7 & 61.3 & 1040 & 1068 \\
\hline & 36 & 145.8 & 148.3 & 15.2 & 15.5 & 729.4 & 753.9 & 64.0 & 65.5 & 1080 & 1106 \\
\hline & 48 & 154.7 & 156.9 & 16.6 & 16.9 & 766.3 & 785.9 & 67.8 & 70.3 & 1160 & 1205 \\
\hline \multirow{4}{*}{ 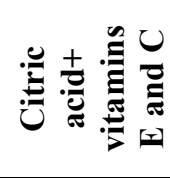 } & 0 & 145.2 & 147.5 & 15.1 & 15.7 & 720.6 & 735.6 & 58.2 & 61.3 & 1090 & 1115 \\
\hline & 24 & 150.1 & 152.1 & 16.5 & 16.8 & 788.7 & 804.9 & 66.0 & 67.9 & 1156 & 1189 \\
\hline & 36 & 153.0 & 155.5 & 17.4 & 17.8 & 826.2 & 842.8 & 70.4 & 72.1 & 1196 & 1227 \\
\hline & 48 & 161.8 & 164.1 & 18.8 & 19.3 & 863.1 & 874.9 & 74.1 & 76.8 & 1276 & 1325 \\
\hline \multicolumn{2}{|l|}{$\mathbf{L S D}_{0.05}$} & 1.6 & 1.4 & 0.7 & 0.8 & 14.5 & 12.9 & 1.3 & 1.5 & 19.8 & 21.6 \\
\hline
\end{tabular}


Table (4). Effect of antioxidants and potassium levels and their interaction on harvest index, shelling, seed protein and oil content and oil yield of sunflower during 2015 and 2016 growing seasons.

\begin{tabular}{|c|c|c|c|c|c|c|c|c|c|c|c|}
\hline \multirow{2}{*}{\multicolumn{2}{|c|}{ Treatment }} & \multicolumn{2}{|c|}{$\begin{array}{c}\text { Harvest } \\
\text { index } \\
(\%) \\
\end{array}$} & \multicolumn{2}{|c|}{$\begin{array}{c}\text { Shelling } \\
(\%)\end{array}$} & \multicolumn{2}{|c|}{$\begin{array}{c}\text { Seed protein } \\
(\%)\end{array}$} & \multicolumn{2}{|c|}{$\begin{array}{l}\text { Seed oil } \\
(\%)\end{array}$} & \multicolumn{2}{|c|}{$\begin{array}{c}\text { Oil yield } \\
\text { (kg/feddan) }\end{array}$} \\
\hline & & 2015 & 2016 & 2015 & 2016 & 2015 & 2016 & 2015 & 2016 & 2015 & 2016 \\
\hline \multicolumn{12}{|c|}{ Antioxidant, ppm (A) } \\
\hline \multirow{6}{*}{\multicolumn{2}{|c|}{$\begin{array}{l}\text { Without, } 0 \\
\text { Citric acid, } 500 \\
\text { Vitamin E, } 50 \\
\text { Vitamin C, } 100 \\
\text { Citric acid+Vitamins E and C } \\
\text { LSD }_{0.05}\end{array}$}} & 23.6 & 24.8 & 50.3 & 50.7 & 14.1 & 14.5 & 31.6 & 33.1 & 304 & 322 \\
\hline & & 29.5 & 30.7 & 55.6 & 56.8 & 14.8 & 15.0 & 35.0 & 36.2 & 378 & 397 \\
\hline & & 31.8 & 32.6 & 59.2 & 60.6 & 15.6 & 15.7 & 36.9 & 38.6 & 435 & 474 \\
\hline & & 25.6 & 26.5 & 53.1 & 53.9 & 16.1 & 16.3 & 33.4 & 34.1 & 340 & 356 \\
\hline & & 33.4 & 34.1 & 61.5 & 62.8 & 16.4 & 16.6 & 37.8 & 39.3 & 470 & 505 \\
\hline & & 1.8 & 1.7 & 2.5 & 2.3 & 0.5 & 0.4 & 1.2 & 1.1 & 35.1 & 32.5 \\
\hline \multicolumn{12}{|c|}{ Potasium sulphate, $\mathrm{kg} \mathrm{K}_{2} \mathrm{O} /$ feddan } \\
\hline $\mathbf{0}$ & & 21.9 & 23.0 & 48.8 & 49.9 & 13.7 & 14.0 & 29.4 & 30.7 & 296 & 315 \\
\hline 24 & & 27.3 & 27.9 & 55.9 & 57.0 & 14.9 & 15.6 & 33.6 & 34.2 & 361 & 375 \\
\hline 36 & & 31.4 & 32.5 & 60.7 & 61.5 & 16.1 & 16.5 & 35.5 & 37.4 & 410 & 440 \\
\hline & & 37.8 & 38.4 & 64.6 & 65.4 & 16.8 & 17.4 & 38.7 & 40.8 & 509 & 530 \\
\hline $\mathbf{L S D}_{0.05}$ & & 3.2 & 3.6 & 3.1 & 3.8 & 0.6 & 0.8 & 1.7 & 2.0 & 21.6 & 25.7 \\
\hline \multicolumn{12}{|l|}{$\mathbf{A} \times \mathbf{P}$} \\
\hline \multirow{4}{*}{$\sum_{i=0}^{0}$} & $\mathbf{0}$ & 22.2 & 23.9 & 49.5 & 50.2 & 13.9 & 14.2 & 30.5 & 31.9 & 289.7 & 306.3 \\
\hline & 24 & 24.9 & 26.3 & 53.0 & 53.8 & 14.5 & 15.0 & 32.6 & 33.6 & 330.8 & 347.9 \\
\hline & 36 & 27.0 & 28.6 & 55.4 & 56.0 & 15.1 & 15.5 & 33.5 & 35.2 & 356.2 & 379.7 \\
\hline & 48 & 30.2 & 31.6 & 57.4 & 58.0 & 15.4 & 15.9 & 35.1 & 36.9 & 405.5 & 439.9 \\
\hline \multirow{4}{*}{ 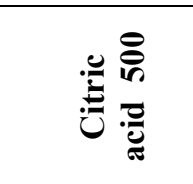 } & 0 & 25.7 & 26.8 & 52.1 & 53.3 & 14.2 & 14.3 & 32.2 & 33.4 & 326.8 & 343.9 \\
\hline & 24 & 28.4 & 29.3 & 55.7 & 56.8 & 14.8 & 14.5 & 34.3 & 35.1 & 368.9 & 385.5 \\
\hline & 36 & 30.4 & 31.6 & 58.1 & 59.1 & 15.4 & 15.3 & 35.2 & 36.7 & 393.2 & 417.3 \\
\hline & 48 & 33.6 & 34.5 & 60.0 & 61.0 & 15.8 & 15.7 & 36.8 & 38.4 & 442.6 & 477.5 \\
\hline \multirow{4}{*}{ 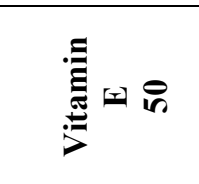 } & $\mathbf{0}$ & 26.8 & 27.8 & 54.2 & 55.2 & 14.6 & 14.8 & 33.1 & 34.6 & 355.3 & 382.1 \\
\hline & 24 & 29.5 & 30.2 & 57.5 & 58.7 & 15.2 & 15.6 & 35.2 & 36.3 & 397.4 & 423.7 \\
\hline & 36 & 31.6 & 32.5 & 60.0 & 60.9 & 15.8 & 16.1 & 36.1 & 37.9 & 421.7 & 455.5 \\
\hline & 48 & 34.8 & 35.4 & 61.8 & 62.9 & 16.2 & 16.5 & 37.7 & 39.6 & 471.1 & 515.7 \\
\hline \multirow{4}{*}{ 苗 } & $\mathbf{0}$ & 23.7 & 24.7 & 50.9 & 51.8 & 14.9 & 15.1 & 31.4 & 32.4 & 308.7 & 323.4 \\
\hline & 24 & 26.4 & 27.2 & 54.4 & 55.4 & 15.5 & 15.9 & 33.5 & 34.1 & 349.8 & 365.0 \\
\hline & 36 & 28.5 & 29.5 & 56.8 & 57.6 & 16.1 & 16.4 & 34.4 & 35.7 & 376.1 & 396.8 \\
\hline & 48 & 31.7 & 32.4 & 58.8 & 59.6 & 16.4 & 16.8 & 36.0 & 37.4 & 425.5 & 457.0 \\
\hline \multirow{4}{*}{ 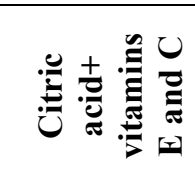 } & $\mathbf{0}$ & 27.6 & 28.5 & 55.1 & 56.3 & 15.0 & 15.3 & 33.6 & 35.0 & 372.7 & 397.7 \\
\hline & 24 & 30.3 & 31.0 & 58.6 & 59.8 & 15.6 & 16.1 & 35.6 & 36.7 & 414.7 & 439.4 \\
\hline & 36 & 32.4 & 33.3 & 61.0 & 62.0 & 16.2 & 16.5 & 36.6 & 38.3 & 439.1 & 471.1 \\
\hline & 48 & 35.5 & 36.2 & 62.9 & 64.0 & 16.6 & 17.0 & 38.2 & 40.0 & 488.4 & 531.4 \\
\hline LSD $_{0.05}$ & & NS & NS & 1.2 & 1.3 & NS & NS & 0.6 & 0.5 & 18.6 & 17.4 \\
\hline
\end{tabular}




\section{Potassium}

Regarding the effect of $\mathrm{K}$ fertilizer levels on sunflower yield and its attributes, results in tables ( 3 and 4 ) reveal that increasing $\mathrm{K}$ rates from 0 to $48 \mathrm{~kg} \mathrm{~K} \mathrm{~K}_{2} \mathrm{O} /$ feddan caused significant increases in plant height, head diameter, seeds number/head, 1000 -seed weight, seed yield, harvest index $\%$, shelling $\%$, seed protein $\%$, oil $\%$ and oil yield of sunflower plants in both seasons. Thus, adding $48 \mathrm{~kg} \mathrm{~K} 2 \mathrm{O} /$ feddan was the efficient treatment in this respect being recorded the highest values surpassing both of 36 and 24 $\mathrm{kg} \mathrm{K} 2 \mathrm{O}$ /feddan treatments for all studied traits. Moreover, without potassium fertilizer (control) was the inferior treatment in this concern in both seasons. The increments associated with application of $48 \mathrm{~kg} \mathrm{~K} 2 \mathrm{O} /$ feddan reached 25.73 and $25.40 \%$ for plant height, 58.87 and $55.81 \%$ for head diameter, 48.68 and $46.32 \%$ for number of seeds per head, 70.57 and $62.75 \%$ for 1000 -seed weight, 39.60 and $44.27 \%$ for seed yield as well as 72.60 and $66.96 \%$ for harvest index, 32.38 and $31.06 \%$ for shelling \%, 22.63 and $24.29 \%$ for seed protein $\%, 31.63$ and $32.90 \%$ for oil percentage and 71.96 and $68.25 \%$ for oil yield/fed in comparison to the control treatment (without potassium fertilizers) in 2015 and 2016 , respectively. These findings might be attributed to one or more of the following K functions; (1) Potassium regulates enzyme activates and translocation from leaves to the roots and also to the storage organs like seeds. (2) Potassium controls both transpiration and respiration and regulates the opening and closing of stomata. (3) Potassium application increases, $\mathrm{CO}_{2}$ assimilation and photosynthesis, important role of potassium in material transfer, leaf made assimilates transfer to productive organs and caused better seed filling and weight. (4) Potassium has important role in water use efficiency and improves plant growth condition, cell division and makes of hydrocarbon, protein and quick transportation toward grains. (5) Potassium is necessary for regulation of different physco-chemical processes in plants including water utilization by the plant. (6) Potassium affects cell metabolism and regulates cell osmosis and increases absorption of water and photosynthesis finally. (7) Potassium application contributes plants to approach longer root length as well through the condition of drought stress. The positive response of sunflower productivity to potassium application was described by several investigators (Ahmad et al., 2011; Chajjro et al., 2013; Ahmad et al., 2014; Hakan and Zengin, 2014; Jan and Hadi, 2015; Guilherme et al., 2016 and Sabrina et al., 2016).

\section{Antioxidants x Potassium}

Remarkable influence of the interaction between antioxidants foliar application and $\mathrm{K}$ fertilizer levels on all studied traits were obtained, except for harvest index $\%$ and seed protein $\%$ as shown in tables ( 3 and 4 ). Herein, the interaction between spraying sunflower plants by combination of three antioxidants together, citric acid + vitamin $\mathrm{E}+$ vitamin $\mathrm{C}$, and adding a high 
rate of potassium, $48 \mathrm{~kg} \mathrm{~K} 2 \mathrm{O} /$ feddan practice gave the maximum values of plant height, head diameter, seeds number/head, 1000-seed weight, seed and oil yield, shelling and oil \% in both seasons. Otherwise, the interaction between without antioxidants and nil potassium fertilizers treatment gave the minimal values in both seasons. Additionally, in plots fertilized with $48 \mathrm{~kg}$ $\mathrm{K}_{2} \mathrm{O} /$ feddan, citric acid + vitamin $\mathrm{E}+$ vitamin $\mathrm{C}$ treatment statistically equalled with vitamin $\mathrm{E}$ one for promoting shelling \%, oil \% and oil yield in both seasons.

\section{CONCLUSION}

According to the above mentioned results, it can be concluded that using a foliar application of citric acid + vitamin $\mathrm{E}+$ vitamin $\mathrm{C}$, along with potassium fertilizer ( $48 \mathrm{~kg} \mathrm{~K}_{2} \mathrm{O} /$ feddan) attained high sunflower yield and components and oil yield under the conditions of the North Sinai Governorate. It is of interest to mention here that, the spraying at $50 \mathrm{ppm}$ vitamin $\mathrm{E}$ as antioxidant and adding $48 \mathrm{~kg} \mathrm{~K} 2 \mathrm{O}$ /feddan as $\mathrm{K}$ fertilizer is the best cardinal method to achieve the optimum and economical productivity of sunflower plants under sandy soil conditions. Consequently, enhancing environmental sustainability and minimizing land degradation in this region. Moreover, reducing the gap between the production and consumption, this exceeds $95 \%$ and providing the great demand of edible oils for facing the highly increasing human population in Egypt.

\section{REFERENCES}

Abd El-Hakim, W.M. (2006). Effect of some antioxidant treatments on chemical constituents, antinutritional factors and yield of some vegetable legumes. Ph.D. Thesis, Fac. of Agric., Minia Univ., Minia, Egypt.

Abdou, M., M. Abdalla, A. Hegazy and S. Marzouk (2011). Physiological studies on clove Basil plant. J. Plant Production, Mansoura Univ., 11: 1451-1469.

Ahmad, A.H., M.A. Bukhsh, A. Riaz, J. Iqbal, S. Hussain, A. Rehman and M. Ishaque (2011). Potassium application reduces bareness in different maize hybrids under crowding stress conditions. Pak. J. Agri. Sci., 48 (1): $41-48$.

Ahmad, R., E. Waraich, M.Y. Ashraf, S. Ahmad and T. Aziz (2014). Does nitrogen fertilization enhance drought tolerance in sunflower? A review. J. Plant Nutr., 37: 942-963.

Ali, A., N. Azzaz and E. Hassan (2006). Influence of spraying active dry yeast, methionine and ascorbic acid on growth, yield and oil of anise (Pimpinella anisum L.) plants. Minia J. Agric. Res. Develop., (26): 683-716. 
Al-Qubaie, A.I. (2012). Response of sunflowers cultivar Giza-102 (Helianthus annuus L.) plants to spraying some antioxidants. Nature and Science, 10 (11): 1-6.

Anonymous (2013). Oilseeds and products annual. USDA Foreign Agricultural Service, Global Agricultural Information Network (GAIN Report). Available online: http://gain.fas.usda.gov

A.O.A.C. (1995). In "Official Methods of Analysis". 16th Ed, A.O.A.C Benjamin Franklin Station, Washington, D.C, USA, pp. 490-510.

Aono, M., A. Kubo, H. Saji, K. Tanaka and N. Kondo (1993). Enhanced tolerance to photo-oxidative stress of transgenic (Nicoliana lahaci) with high chloroplastic glutathione reductase activity. Plant Cell Physiol., 34: 129-135.

Beadle, C.L. (1987). In "Plant Growth Analysis". Techniques in Bioproductivity and Photosynthesis. 2nd Ed. Coombs, J., D.O. Hall, S.P. Long and J.M.O. Sacrlock (Eds.). Pregamon Press., Oxford, New York. USA, pp, 21-23.

Cakmak, I. (2005). The role of potassium in alleviation detrimental effects of abiotic stresses in plants. J. Plant Nutr. Soil Sci., 168 (4): 521-530.

Chajjro, M.A, Z.I. Hassan, A.N. Shah and K.A. Kubar (2013). Sunflower hybrids differentially accumulate potassium for growth and achene yield. Pak. J. Agri., Agril. Eng., Vet. Sci., 29 (1): 31-43.

El-Bassiouny, H.M.S., M.E. Gobarah and A.A. Ramadan (2005). Effect of antioxidants on growth, yield and favism causative agents in seeds of Vicia faba L. plants grown under reclaimed sandy soil. J. Agric., 4: 281-287.

Farooq, M., S.M. Basra, A. Wahid, N. Ahead and B.A. Saleem (2009). Improving the drought tolerance in rice (Oryza sativa L.) by exogenous application of salicylic acid. J. Agron. Crop Sci., 195: 237246.

Feitosa, H.O., G.C. Farias, R.J. Silva, F.J. Ferreira, F.L. Andrade and C.F. Lacerda (2013). Influence of potassium fertilization and borácica performance sunflower. Comunicata. Sci., 4 (3): 302-307.

Foyer, C.H, A.J. Bloom, G. Queval, G. Noctor (2009). Photorespiratory metabolism: genes, mutants, energetics and redox signaling. Annu. Rev. Plant Biol., 60: 455-484.

Gad El-Hak, S.H., Y.T. Abdel-Mageed, A.A. Galal, N.S. Youssef and A.Z. Osman (2002). Influence of antioxidants and calcium chloride on potato growth and yield. Proc. Minia $1{ }^{\text {st }}$ Conf. for Agric. And Environ. Sci., Minia, Egypt, March 25-28.

Galal, A.A., Gad El-Hak, S.H. Abdel-Ati, Y.Y. Moustafa and Y.M.M., (2000). Response of new tomato hybrids to some antioxidants and early blight. The 2nd Scientific Conference of Agricultural Sciences, Assuit, Egypt, pp. 673-686. 
Guilherme, F.D. Xavier, E. Andrade, G. Lima and L.C. Wanderley (2016). Growth and physiological responses of sunflower grown under levels of water replacement and potassium fertilization. Afr. J. Agric. Res., 11 (14): 1273-1281.

Hakan, E. and M. Zengin (2014). Response of sunflower to potassium and magnesium fertilizers in calcareous soils in central Anatolia of Turkey. Journal of Plant Nutrition, 39 (12): 547-543.

Ibrahim, T.I.E. (2010). Physiological studies on geranium plants. M. Sc. Thesis, Fac. of Agric., Minia Univ., Egypt.

Jan, A.U. and F. Hadi (2015). Potassium, zinc and gibberellic acid foliar application enhanced salinity stress tolerance, proline and total phenolic contents in sunflower (Helianthus annuus L.). AmericanEurasian J. Agric. Environ. Sci., 15 (9): 1835-1844.

Kamal, M., M.F. Saleem, M.A. Wahid and A. Shakeel (2017). Effect of ascorbic acid on membrane stability and yield of heat-stressed at cotton. J. Anim. Plant Sci., 27 (1): 857-866.

Karadeniz, F., H.S. Burdurlu, N. Koca and Y. Soyer (2005). Antioxidant activity of selected fruits and vegetables grown in Turkey. Turk. J. Agric., 29: 197-203.

Klute, A. (1986). Water retention: Methods of soil analysis, part 1. Physical and mineralogical methods. Amer. Soc. Agron. Madison, 9: 635- 662.

Marchand, M. (2007). Potassium fertilization and water use efficiency under saline conditions. International Fertilizer Correspondent, Ed. 13. Available online: https://www.ipipotash.org/en/eifc/2007/13/1/English

Maurice, R.M., J. Kim and C.I. Wei (2000). Enzymatic browning in fruits, vegetables and sea foods. Food Science and Human Nutrition Department, University of Florida, 65: 791-795.

Mead, R., R.N. Currnow and A.M. Harted (1993). In: "Statistical Methods in Agriculture and Experimental Biology". Second Ed. Chapman and Hall, London, pp. 10-44.

Menezes, R.S.C. and T.S. Oliveira (2008). Soil fertility changes in an Entisol following six years of application of organic manure. Rev. Bras. Eng. Agric. Ambient., 12 (3): 251-257.

Muhammad, A., B. Amanullah and A. Mohammad (2011). Phenology, leaf area and yield of spring maize (cv. Azam) as affected by levels and timings of potassium application. World Appl. Sci. J., 2 (4): 299- 303.

Osman, E.A.M., M.A. El-Galad, K.A. Khatab and M.A.B. El-Sherif (2014). Effect of compost rates and foliar application of ascorbic acid on yield and nutritional status of sunflower plants irrigated with saline water. Global Journal of Scientific Researches, 2 (6): 193-200.

Page, A., R. Miller and D.R. Keeney (1982). In "Methods of Soil Analysis". Second Madison WI, USA: ASA and SSSA Publisher.

Prado, R.M. and R.M. Leal (2006). Nutritional disorders by deficiency in sunflower var. catissol-01. Pesqui. Agropecu. Trop., 36 (3): 187- 193. 
Rajagopal, S., D. Joly, A. Gauthier, M. Beauregard and R. Carpentier (2005). Protective effect of active oxygen scavengers on protein degradation and photochemical functions during light stress. FEBS. J., 27: 892-902.

Reda, F., E.A. Abdel-Rahim, G.S. El-Baroty and H.S. Ayad (2005). Responce of essential oil, phenolic components and polyphenol oxidative activity of Thyme (Thymus vulgaris L.) to some bioregulators and vitamins. Int. J. Agric. Biol., 7 (5): 735-739.

Sabrina, T.S., V.F. Karina, M.P. Angela and C.A. Iracema (2016). Alternative potassium source for the cultivation of ornamental sunflower. Ciencia Agro. Tecnologia, 40 (3): 257-264.

Sadiq, M., N. Akram and M. Ashraf (2017). Foliar applications of alphatocopherol improves the composition of fresh pods of Vigna radiate subjected to water deficiency. Turk. J. Bot., 41: 244-252.

Saleh, S.A., N.M. Abd El-Gawad and A.A. Omran (2004). Response of some sunflower cultivars to some bio nitrogen fertilization under hill spaces. J. Agric. Sci. Mansoura Univ., 29 (12): 6775-6786.

Smirnoff, N. and G.L. Wheeler (2000). Ascorbic acid in plants. Biosynthesis and Function. Crit. Rev. Plant Sci., 19: 267-290.

Uchoa, S.C., M.E. Ivanoff, J.M. Alves, T. Sediyama and A.S. Martins (2011). Potassium fertilization in sidedressing in the yield components of sunflower cultivars. Rev. Ciênc. Agron., 42 (1): 8-15.

Wang, G.P., Z. Hui, F. Li, F.M. Zhao, J. Zhang and W. Wang (2010). Improvement of heat and drought photosynthetic tolerance in wheat by over accumulation of glycinebetaine. Plant Biotech. Rep., 4: 213222.

Egyptian J. Desert Res., 68, No. 1, 61-74 (2018) 


\section{تأثير مضادات الأكسدة والبوتاسيوم على إنتاجية دوار الثمس بالتربة الرملية}

\section{عماد محمد محمد سالم " وحسام الدين أحمد ثابت شومان}

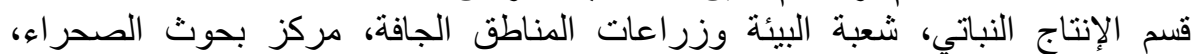

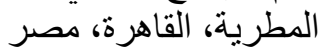

أقيمت تجربتان حقليتان بالمحطة البحثية بمنطقة بالوظة التابعة لمركز بحوث الصحر أراء

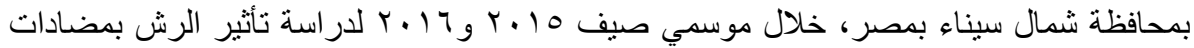

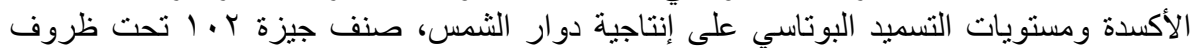

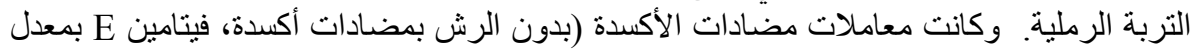

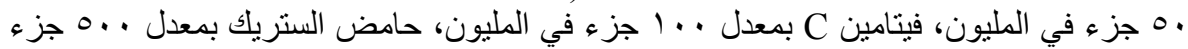

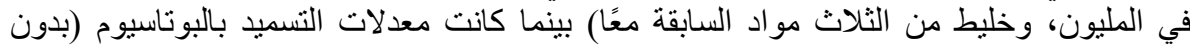

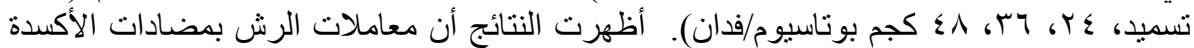

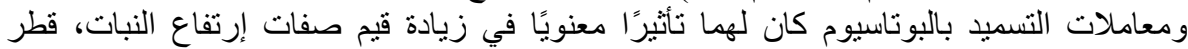

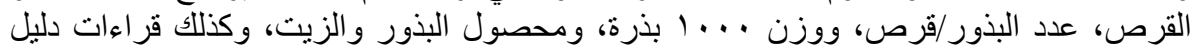

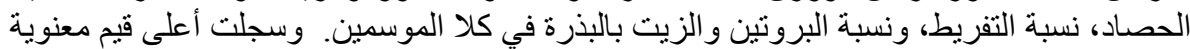

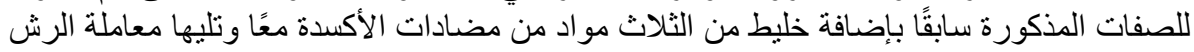

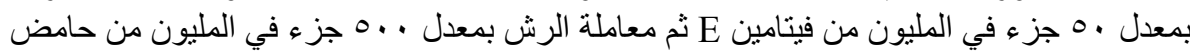

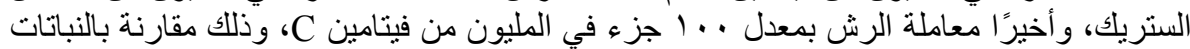

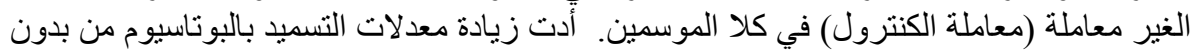

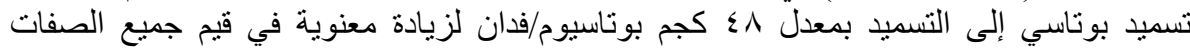

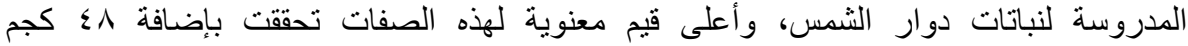

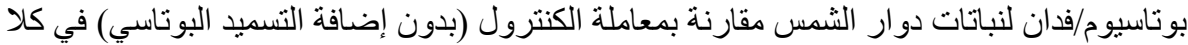

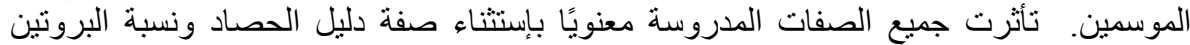
بالبذرة بالتفاعل بين معاملات الرش بمضادات الأكسدة ومعاملات التسميد بالبوت التاسيوم. 